\title{
Kelayakan Kualitas Perairan Teluk Lalong Luwuk Dengan Menggunakan Bio-Indikator Fitoplankton
}

\author{
Sri Sukari Agustina \\ Staf Pengajar Fakultas Perikanan Universitas Muhammadiyah Luwuk
}

\begin{abstract}
Abstrak
Penelitian ini bertujuan untuk menganalisis struktur komunitas fitoplankton yang meliputi kelimpahan, keanekaragaman, keseragaman, dan dominansi serta tingkat pencemaran yang terjadi dan hubungannya dengan kelimpahan fitoplankton di perairan Teluk Lalong Luwuk. Pengambilan data dilakukan dengan menggunakan metode survei lapangan, yaitu melalui observasi dan inventarisasi. Pengambilan sampel fitoplankton dilakukan pada sembilan titik sampling di sekitar perairan Teluk Lalong dengan menggunakan metode sampel random. Sampel fitoplankton yang diperoleh diidentifikasi jenis fitoplankton. Hasil penelitian menunjukkan bahwa jenis fitoplankton yang didapatkan di perairan Teluk Lalong antara lain : Chaetoceros sp, Skeletonema sp, Nitzschia sp, Pontosphaera sp, Dinobryon sp, Ceratium sp, dan Coscinodiscus sp. Kelimpahan individu berkisar antara 1.274-29.300 ind/L, indeks keanekaragaman berkisar antara 0-1,19355, indeks keseragaman berkisar antara 0-0,999997, indeks dominansi berkisar antara 0,33333-1. Berdasarkan kelimpahan fitoplankton, perairan Teluk Lalong dikategorikan oligotrofik, mesotrofik dan eurotrofik. Sedangkan Berdasarkan indeks keanekaragaman, perairan Teluk Lalong dikategorikan tercemar sedang dan tercemar berat.
\end{abstract}

Kata kunci : Fitoplankton, kelimpahan, keanekaragaman, keseragaman, dominansi, pencemaran

\section{Feasibility Of The Quality Of Waters Of The Bay Lalong Luwuk By Using Bio-Indicators of Phytoplankton}

\begin{abstract}
This study aims to analyze the structure of phytoplankton communities which includes the abundance, diversity, uniformity, and dominance as well as the level of pollution that occurs and its relationship with the abundance of phytoplankton in the waters of the Bay Lalong Luwuk. Data is collected using field survey methods, namely through observation and inventory. Phytoplankton sampling conducted at nine sampling points around the waters of the Bay Lalong using random sampling method. Phytoplankton samples obtained identified the type of phytoplankton. The results showed that the type of phytoplankton found in the waters of the Bay Lalong include: Chaetoceros sp, Skeletonema sp, Nitzschia sp, Pontosphaera sp, Dinobryon sp, Ceratium sp, and Coscinodiscus sp. Abundance of individuals ranged between 1274-29300 ind/L, the index of diversity ranged from 0 to 1.19355 , uniformity index ranges from 0 to 0.999997 , the dominance index ranged from 0.33333 to 1 . Based on the abundance of phytoplankton, the waters of the Bay of Lalong categorized oligotrofik, mesotrofik and eurotrofik. Meanwhile based on diversity index, waters of the Bay Lalong are being polluted categorized and heavily polluted.
\end{abstract}

Key words: Phytoplankton, abundance, diversity, uniformity, dominance, pollution 


\section{PENDAHULUAN}

Teluk Lalong merupakan perairan yang sangat subur sebagai akibat dari pasokan nutrien yang sangat melimpah dan sungaisungai yang melintasi Luwuk. Perairan Teluk Lalong dimanfaatkan oleh manusia untuk berbagai kegiatan sebagai pintu gerbang hubungan lalu lintas antar provinsi dan kabupaten, sebagai obyek pariwisata dan juga sebagai perairan penampung bahan-bahan buangan yang dimuntahkan ke dalam teluk oleh aliran sungai dari daratan.

Dalam hubungannya dengan keadaan ekosistem perairan Teluk Lalong, faktor kepadatan penduduk Luwuk yang tinggi disamping berbagai kegiatan industri yang terus berkembang dan pola penggunaan tanah yang intensif, baik langsung maupun tak langsung dapat memberikan tekanan-tekanan yang terus meningkat terhadap ekosistem perairan Teluk Lalong. Adanya berbagai macam tekanan terhadap lingkungan laut menyebabkan kondisi perairan Teluk Lalong mengalami kemunduran sepanjang tahun.

Perubahan terhadap kualitas perairan erat kaitannya dengan potensi perairan ditinjau dari kelimpahan dan komposisi fitoplankton. Keberadaan fitoplankton di suatu perairan bisa memberikan informasi mengenai kondisi perairan. Fitoplankton merupakan parameter biologi yang dapat dijadikan indikator untuk mengevaluasi kualitas dan tingkat kesuburan suatu perairan. Fitoplankton juga merupakan penyumbang oksigen terbesar di dalam perairan laut. Pentingnya peranan fitoplankton sebagai pengikat awal energi matahari menjadikan fitoplankton berperan penting bagi kehidupan laut. Keberadaan fitoplankton memang dapat dijadikan indikator kualitas perairan di Teluk Lalong.

Tujuan daripada penelitian ini adalah untuk menganalisis struktur komunitas fitoplankton yang meliputi kelimpahan, keanekaragaman, keseragaman, dan dominansi serta tingkat pencemaran yang terjadi dan hubungannya dengan kelimpahan fitoplankton di perairan Teluk Lalong Luwuk Kabupaten Banggai.

\section{METODE PENELITIAN}

Penelitian ini dilaksanakan pada bulan Juli sampai dengan bulan Agustus 2011. Metode yang digunakan untuk pengambilan data dalam penelitian ini adalah metode survei. Pengambilan sampel fitoplankton dilakukan pada sembilan titik sampling di sekitar perairan Teluk Lalong Luwuk Kabupaten Banggai dengan menggunakan metode sampel random (Clark dan Hosking, 1986). Fitoplankton dikoleksi menggunakan plankton net no. 25. Sampel fitoplankton yang diperoleh diidentifikasi jenis fitoplankton dengan bantuan mikroskop berpedoman pada Newel dan Newel (1977), serta Yamaji (1976). Kemelimpahannya dihitung menggunakan rumus counting cell (APHA, 2003). Analisis kuantitatif indeks biologi fitoplankton meliputi perhitungan keragaman, keseragaman dan dominansi dari ShannonWiener (Odum, 1971; Basmi, 2000). Perbedaan kelimpahan, keragaman, keseragaman dan dominansi fitoplankton dianalisis secara deskriptif.

\section{Kelimpahan fitoplankton :}

$$
\begin{aligned}
\mathrm{N} & =\frac{100(P X \mathrm{~V})}{0,25 \pi \mathrm{W}} \\
\mathrm{N} & =\begin{array}{l}
\text { Jumlah plankton per liter } \\
\mathrm{P}
\end{array} \\
\mathrm{V} & =\begin{array}{l}
\text { Jumlah plankton yang tercacah } \\
\text { Volume sampel plankton yang } \\
\mathrm{tersaring}(\mathrm{ml})
\end{array} \\
\mathrm{W} & =\begin{array}{l}
\text { Volume sampel plankton yang } \\
\text { disaring }(\mathrm{L})
\end{array}
\end{aligned}
$$

\section{Indeks keanekaragaman :}

$$
\begin{aligned}
& \mathrm{H}^{\prime}=-\mathrm{Pi} \ln \mathrm{Pi} \\
& \mathrm{P}=\mathrm{ni} / N \\
& \mathrm{H}^{\prime}=\text { Indeks keanekaragaman jenis } \\
& \mathrm{ni}=\text { Jumlah individu taksa ke-i } \\
& \mathrm{N}=\text { Jumlah total individu } \\
& \mathrm{Pi}=\text { Proporsi spesies ke- } \mathrm{i}
\end{aligned}
$$


Indeks keseragaman :

$$
\begin{aligned}
& E=\frac{H^{\prime}}{H_{\text {maks }}} \\
& \mathrm{E}=\text { Indeks keseragaman spesies } \\
& \mathrm{H} \text { maks }=\ln S \text { ( } S \text { adalah jumlah spesies } \\
& \text { penyusun komunitas) } \\
& \mathrm{H}^{1}=\text { Indeks keanekaragaman }
\end{aligned}
$$

\section{Indeks dominansi :}

$$
\begin{aligned}
& \mathrm{D}=(\mathrm{Pi})^{2} \\
& \mathrm{D}=\text { Indeks Dominansi } \\
& \mathrm{Ni}=\text { Jumlah individu taksa ke-i } \\
& \mathrm{N}=\text { Jumlah total individu } \\
& \mathrm{Pi}=\mathrm{ni} / \mathrm{N}=\text { Proporsi spesies ke-i }
\end{aligned}
$$

\section{HASIL DAN PEMBAHASAN}

\section{Struktur Komunitas Fitoplankton Di Perairan Teluk Lalong}

Berdasarkan hasil pemeriksaan dan hasil analisis fitoplankton pada enam stasiun (P1, P2, P3, P4, P5 dan P6) yang terdapat di perairan Teluk Lalong didapatkan data fitoplankton pada Tabel 1 dan Tabel 2. Pada Tabel 1 dimana pengambilan sampel fitoplankton pada waktu pagi hari (07.00 08.00 WITA) di perairan Teluk Lalong Luwuk Kabupaten Banggai didapatkan nilai kelimpahan fitoplankton pada kisaran $1.274-8.917$ sel/L $(4.458,67 \quad \pm$ 3.197,24). Jumlah spesies plankton yang ditemukan pada kisaran 1-3 spesies, yang secara keseluruhan didominasi oleh diatom dari jenis Skeletonema sp dan Nitzshia sp. Nilai kelimpahan fitoplankton tertinggi stasiun P2 (perairan depan gedung DPRD) sebesar $7.643 \mathrm{sel} / \mathrm{L}$.

Sedangkan pada Tabel 2 dimana pengambilan sampel fitoplankton pada waktu siang hari (13.30-14.30 WITA) pada perairan Teluk Lalong Luwuk Kabupaten Banggai didapatkan nilai kelimpahan fitoplankton pada kisaran 1.274-29.300 sel/L $\quad(9.554,50 \quad \pm$ $10.435,22)$. Jumlah spesies plankton yang ditemukan pada kisaran 1-4 spesies, yang secara keseluruhan didominasi oleh diatom dari jenis Nitzshia sp. Nilai kelimpahan fitoplankton tertinggi pada stasiun P2 (perairan depan Gedung DPRD) sebesar $29.300 \mathrm{sel} / \mathrm{L}$.
Nilai rata-rata kelimpahan plankton pada stasiun P2 (perairan depan gedung DPRD) lebih tinggi dibandingkan nilai ratarata kelimpahan plankton dari semua stasiun baik pada waktu pengambilan fitoplankton pagi hari maupun siang hari, ini mengindikasikan bahwa pada wilayah perairan depan gedung DPRD mempunyai tingkat kesuburan lebih tinggi dibandingkan perairan lainnya diduga karena dekat dengan muara sungai dan merupakan sumber cemaran berupa limbah perkotaan dan industri yang mengalir ke perairan.

Landner (1978) dalam Basmi (2000) menyatakan bahwa berdasarkan kesuburan nutrien, perairan dikategorikan menjadi tiga kondisi yaitu perairan eutrofik (kondisi dengan kandungan nutrien tinggi dimana kualitas perairan mengalami penurunan) dengan kelimpahan fitoplankton lebih dari $15.000 \mathrm{ind} / \mathrm{L}$, perairan mesotrofik (kondisi dengan kandungan nutrien sedang) dengan kelimpahan fitoplankton 2.000-15.000 ind/L dan perairan oligotrofik (kondisi dengan kandungan nutrien yang miskin) dengan kelimpahan fitoplankton $0-2.000$ ind/L. Berdasarkan hal ini, maka stasiun P2 (perairan depan gedung DPRD) dapat digolongkan perairan eutrofik, stasiun P3 (perairan depan CFC), P4 (perairan muara sungai Maleo), P5 (perairan pelabuhan kapal kayu), P6 (perairan pelabuhan kapal veri) dapat digolongkan perairan mesotrofik, sedangkan stasiun P1 (perairan pelabuhan Tilong) dapat digolongkan perairan oligotrofik

Hasil analisis pada Tabel 1 dan Tabel 2, indeks keanekaragaman (H') fitoplankton memperlihatkan di perairan Teluk lalong pada stasiun P1, P2, P4 dan P6 berkisar antara 0-0,95567 berarti termasuk komunitas biota tidak stabil atau kualitas air tercemar berat. Sedangkan stasiun P3 dan P5 berkisar antara 1,0986-1,19355 berarti stabilitas komunitas biota sedang atau kualitas air tercemar sedang. Menurut Stirn (1981) apabila $\mathrm{H}^{\prime}<1$, maka komunitas biota dinyatakan tidak stabil, apabila $\mathrm{H}^{\prime}$ berkisar 1-3 maka stabilitas komunitas biota tersebut adalah moderat (sedang) dan apabila $\mathrm{H}^{\prime}>3$ berarti stabilitas komunitas biota berada dalam kondsi prima (stabil). Semakin besar nilai $\mathrm{H}^{\prime}$ menunjukkan semakin beragamnya kehidupan di perairan tersebut, kondisi ini 
Tabel 1. Data fitoplankton pengambilan pagi hari (07.00-08.00 WITA) di lokasi penelitian perairan Teluk Lalong

\begin{tabular}{|c|c|c|c|c|c|c|c|c|c|c|c|c|c|}
\hline \multirow[b]{3}{*}{ No } & \multirow{3}{*}{$\begin{array}{c}\text { Jenis } \\
\text { Fitoplankton }\end{array}$} & \multicolumn{12}{|c|}{ Stasiun (Lokasi penelitian) } \\
\hline & & \multicolumn{2}{|r|}{$\mathrm{P} 1$} & \multicolumn{2}{|c|}{$\mathrm{P} 2$} & \multicolumn{2}{|c|}{$\mathrm{P} 3$} & \multicolumn{2}{|c|}{$\mathrm{P} 4$} & \multicolumn{2}{|c|}{ P5 } & \multicolumn{2}{|r|}{ P6 } \\
\hline & & $\begin{array}{l}\text { Plankton } \\
\text { yang } \\
\text { tercacah } \\
(\mathrm{mL})\end{array}$ & $\begin{array}{c}\text { Kelimpahan } \\
\text { individu } \\
\text { (ind/L) }\end{array}$ & $\begin{array}{l}\text { Plankton } \\
\text { yang } \\
\text { tercacah } \\
(\mathrm{mL}) \\
\end{array}$ & $\begin{array}{c}\text { Kelimpahan } \\
\text { individu } \\
\text { (ind/L) }\end{array}$ & $\begin{array}{c}\text { Plankton } \\
\text { yang } \\
\text { tercacah } \\
(\mathrm{mL}) \\
\end{array}$ & $\begin{array}{c}\text { Kelimpahan } \\
\text { individu } \\
\text { (ind/L) }\end{array}$ & $\begin{array}{l}\text { Plankton } \\
\text { yang } \\
\text { tercacah } \\
(\mathrm{mL})\end{array}$ & $\begin{array}{c}\text { Kelimpahan } \\
\text { individu } \\
\text { (ind/L) }\end{array}$ & $\begin{array}{c}\text { Plankton } \\
\text { yang } \\
\text { tercacah } \\
(\mathrm{mL}) \\
\end{array}$ & $\begin{array}{c}\text { Kelimpahan } \\
\text { individu } \\
\text { (ind/L) }\end{array}$ & $\begin{array}{c}\text { Plankton } \\
\text { yang } \\
\text { tercacah } \\
(\mathrm{mL}) \\
\end{array}$ & $\begin{array}{c}\text { Kelimpahan } \\
\text { individu } \\
\text { (ind/L) }\end{array}$ \\
\hline 1 & Chaetoceros sp & 1 & 1274 & & & & & & & & & 4 & 5096 \\
\hline 2 & Skeletonema sp & & & 5 & 6369 & & & & & & & 2 & 2547 \\
\hline 3 & Nitzschia sp & & & 1 & 1274 & 3 & 3822 & & & 1 & 1274 & & \\
\hline 5 & Dinobryon $s p$ & & & & & & & 1 & 1274 & & & 1 & 1274 \\
\hline 6 & Ceratium sp & & & & & & & & & 1 & 1274 & & \\
\hline \multicolumn{2}{|c|}{ Jumlah sel/L } & & 1274 & & 7643 & & 3822 & & 1274 & & 3822 & & 8917 \\
\hline \multicolumn{2}{|c|}{ Jumlah jenis } & & 1 & & 2 & & 1 & & 1 & & 3 & & 3 \\
\hline \multicolumn{2}{|c|}{ Indeks Keanekaragaman $\left(\mathrm{H}^{\prime}\right)$} & & 0 & & 0,4506 & & 0 & & 0 & & 1,0986 & & 0,95567 \\
\hline \multicolumn{2}{|c|}{ Indeks Keseragaman (E) } & & 0 & & 0,650078 & & 0 & & 0 & & 0,99999 & & 0,869888 \\
\hline \multicolumn{2}{|c|}{ Indeks Dominansi (D) } & & 1 & & 0,722193 & & 1 & & 1 & & 0,333333 & & 0,428603 \\
\hline
\end{tabular}

\section{Keterangan :}

P1 : Perairan Pelabuhan Tilong ( $00^{\circ} 57.121^{\prime}$ dan $\left.122^{\circ} 47.729^{\prime}\right)$

P2 : Perairan Depan Gedung DPRD ( $00^{\circ} 57.225^{\prime}$ dan $\left.122^{\circ} 47.683^{\prime}\right)$

P3 : Perairan Depan CFC $\left(00^{\circ} 57.206^{\prime}\right.$ dan $\left.122^{\circ} 47.520^{\prime}\right)$

P4 : Perairan Muara Sungai Maleo ( $00^{\circ} 57.020^{\prime}$ dan $\left.122^{\circ} 47.612^{\prime}\right)$

P5 : Perairan Pelabuhan Kapal Kayu ( $00^{\circ} 56.968^{\prime}$ dan $\left.122^{\circ} 47.747^{\prime}\right)$

P6 : Perairan Pelabuhan Kapal Veri ( $00^{\circ} 57.018^{\prime}$ dan $\left.122^{\circ} 47.804^{\prime}\right)$ 
Tabel 2. Data fitoplankton pengambilan siang hari (13.30-14.30 WITA) di lokasi penelitian perairan Teluk Lalong

\begin{tabular}{|c|c|c|c|c|c|c|c|c|c|c|c|c|c|}
\hline \multirow[b]{3}{*}{ No } & \multirow{3}{*}{$\begin{array}{c}\text { Jenis } \\
\text { Fitoplankton }\end{array}$} & \multicolumn{12}{|c|}{ Stasiun (Lokasi penelitian) } \\
\hline & & \multicolumn{2}{|c|}{ P1 } & \multicolumn{2}{|c|}{ P2 } & \multicolumn{2}{|c|}{ P3 } & \multicolumn{2}{|c|}{ P4 } & \multicolumn{2}{|c|}{ P5 } & \multicolumn{2}{|r|}{ P6 } \\
\hline & & $\begin{array}{l}\text { Plankton } \\
\text { yang } \\
\text { tercacah } \\
(\mathrm{mL}) \\
\end{array}$ & $\begin{array}{c}\text { Kelimpahan } \\
\text { individu } \\
\text { (ind/L) }\end{array}$ & $\begin{array}{l}\text { Plankton } \\
\text { yang } \\
\text { tercacah } \\
(\mathrm{mL}) \\
\end{array}$ & $\begin{array}{c}\text { Kelimpahan } \\
\text { individu } \\
\text { (ind/L) }\end{array}$ & $\begin{array}{l}\text { Plankton } \\
\text { yang } \\
\text { tercacah } \\
(\mathrm{mL}) \\
\end{array}$ & $\begin{array}{c}\text { Kelimpahan } \\
\text { individu } \\
\text { (ind/L) }\end{array}$ & $\begin{array}{l}\text { Plankton } \\
\text { yang } \\
\text { tercacah } \\
(\mathrm{mL})\end{array}$ & $\begin{array}{c}\text { Kelimpahan } \\
\text { individu } \\
\text { (ind/L) }\end{array}$ & $\begin{array}{c}\text { Plankton } \\
\text { yang } \\
\text { tercacah } \\
(\mathrm{mL}) \\
\end{array}$ & $\begin{array}{c}\text { Kelimpahan } \\
\text { individu } \\
\text { (ind/L) }\end{array}$ & $\begin{array}{l}\text { Plankton } \\
\text { yang } \\
\text { tercacah } \\
(\mathrm{mL})\end{array}$ & $\begin{array}{c}\text { Kelimpahan } \\
\text { individu } \\
\text { (ind/L) }\end{array}$ \\
\hline 1 & Chaetoceros sp & & & 3 & 3822 & & & & & & & & \\
\hline 2 & Skeletonema $\mathrm{sp}$ & & & & & & & & & & & & \\
\hline 3 & Nitzschia sp & & & 16 & 20382 & & & & & 4 & 5096 & & \\
\hline 4 & Pontosphaera sp & 1 & 1274 & 3 & 3822 & 1 & 1274 & 5 & 6369 & 4 & 5096 & 3 & 3822 \\
\hline 5 & Dinobryon $s p$ & & & & & 1 & 1274 & & & 1 & 1274 & & \\
\hline 6 & Ceratium $\mathrm{sp}$ & & & 1 & 1274 & & & & & & & & \\
\hline 7 & Coscinodiscus sp & & & & & 1 & 1274 & & & 1 & 1274 & & \\
\hline \multicolumn{2}{|c|}{ Jumlah sel/L } & & 1274 & & 29300 & & 3822 & & 6369 & & 12740 & & 3822 \\
\hline \multicolumn{2}{|c|}{ Jumlah jenis } & & 1 & & 4 & & 3 & & 1 & & 4 & & 1 \\
\hline \multicolumn{2}{|c|}{ Indeks Keanekaragaman (H') } & & 0 & & 0,92018 & & 1,09861 & & 0 & & 1,19355 & & 0 \\
\hline \multicolumn{2}{|c|}{ Indeks Keseragaman (E) } & & 0 & & 0,66377 & & 0,999997 & & 0 & & 0,86096 & & 0 \\
\hline \multicolumn{2}{|c|}{ Indeks Dominansi (D) } & & 1 & & 0,51983 & & 0,33333 & & 1 & & 0,34 & & 1 \\
\hline
\end{tabular}

Sumber : Data primer diolah (2011)

\section{Keterangan :}

P1 : Perairan Pelabuhan Tilong ( $00^{\circ} 57.121^{\prime}$ dan $\left.122^{\circ} 47.729^{\prime}\right)$

P2 : Perairan Depan Gedung DPRD ( $00^{\circ} 57.225^{\prime}$ dan $\left.122^{\circ} 47.683^{\prime}\right)$

P3 : Perairan Depan CFC ( $00^{\circ} 57.206^{\prime}$ dan $\left.122^{\circ} 47.520^{\prime}\right)$

P4 : Perairan Muara Sungai Maleo ( $00^{\circ} 57.020^{\prime}$ dan $\left.122^{\circ} 47.612^{\prime}\right)$

P5 : Perairan Pelabuhan Kapal Kayu ( $00^{\circ} 56.968^{\prime}$ dan $\left.122^{\circ} 47.747^{\prime}\right)$

P6 : Perairan Pelabuhan Kapal Veri ( $00^{\circ} 57.018^{\prime}$ dan $\left.122^{\circ} 47.804^{\prime}\right)$ 
merupakan tempat hidup yang lebih baik. Kondisi di lokasi studi, mudah berubah dengan hanya mengalami pengaruh lingkungan yang relatif kecil.

Nilai keseragaman fitoplankton di perairan Teluk Lalong pada stasiun P1, dan P4 sebesar 0, berarti keseragaman antara spesies rendah, artinya kekayaan individu yang dimiliki masing-masing spesies sangat jauh berbeda, sedangkan P2, P3, P4 dan P5 mendekati 1, artinya keseragaman antar spesies relatif seragam atau jumlah individu masing-masing spesies relatif sama. Hal ini diperkuat Pirzan et al. (2005) yang menyatakan bahwa apabila keseragaman mendekati nol berarti keseragaman antar spesies di dalam komunitas tergolong rendah dan sebaliknya keseragaman yang mendekati satu dapat dikatakan keseragaman antar spesies tergolong merata atau sama.

$$
\text { Nilai indeks dominansi }
$$

fitoplankton di perairan Teluk Lalong pada stasiun P1, P2, P3, P4, dan P6 mendekati 1 berarti terdapat spesies yang mendominasi spesies lainnya atau struktur komunitas dalam keadaan labil dan terjadi tekanan ekologi (stress), sedangkan pada stasiun P5 mendekati 0 berati berarti tidak terdapat spesies yang mendominasi spesies lainnya atau struktur komunitas dalam keadaan stabil. Apabila nilai dominansi mendekati nilai 1 berarti di dalam komunitas terdapat spesies yang mendominansi spesies lainnya, sebaliknya apabila mendekati nilai 0 berarti di dalam struktur komunitas tidak terdapat spesies yang secara ekstrim mendominasi spesies lainnya (Basmi, 2000). Faktor utama yang mempengaruhi jumlah organisme, keragaman jenis dan dominansi antara lain adanya perusakan habitat alami seperti pengkonversian lahan mangrove menjadi tambak atau peruntukan lainnya, pecemaran kimia dan organik, serta perubahan iklim (Widodo, 1997). Untuk mempertahankan tidak terjadinya dominansi spesies tertentu di peraran Teluk Lalong, di samping melestarikan terumbu karang dan padang lamun, perlu juga ditempuh upaya pelestarian dan rehabilitasi ekosistem hutan mangrove, antara lain: (i) hutan mangrove dijaga agar dapat bertumbuh dan berkembang secara alami, dan (ii) hutan mangrove yang telah rusak atau masih dalam tahap perkembangan dibantu dengan melakukan penanaman bibit mangrove.

\section{Tingkat Pencemaran Yang Terjadi Di Perairan Teluk Lalong}

Hasil analisis indeks keanekaragaman di perairan Teluk lalong pada stasiun P1, P3, P2, P4 dan P6 berkisar antara 0-1,09861, sedangkan stasiun P5 berkisar antara 1,09861,19355. Menurut Mason (1981) dalam Effendi (2003) mengenai kriteria indeks keanekaragaman kategori pencemaran yang terlihat pada Tabel 3.

Tabel 3. Kriteria indeks keanekaragaman kategori pencemaran

\begin{tabular}{ccll}
\hline No & $\begin{array}{c}\text { Indeks } \\
\text { keaneka } \\
\text { ragaman }\end{array}$ & $\begin{array}{c}\text { Kategori } \\
\text { keragaman }\end{array}$ & $\begin{array}{c}\text { Kategori } \\
\text { pencemaran }\end{array}$ \\
\hline 1 & $>3$ & $\begin{array}{l}\text { Keragaman } \\
\text { tinggi } \\
\text { Keragamanan } \\
\text { cukup tinggi } \\
\text { Keragaman } \\
\text { sedang }\end{array}$ & $\begin{array}{l}\text { Belum } \\
\text { tercemar } \\
\text { Tercemar } \\
\text { ringan }\end{array}$ \\
Keragaman & $\begin{array}{l}\text { Tercemar } \\
\text { sedang } \\
\text { Tercemar } \\
\text { rendah }\end{array}$ & berat \\
\hline
\end{tabular}

Sumber: Mason (1981) dalam Effendi (2003)

Indeks keanekaragaman di perairan

Teluk lalong pada stasiun P1, P3, P2, P4 dan

P6 berkisar antara 0-1,09861 berarti termasuk komunitas biota tidak stabil atau kualitas air tercemar berat. Sedangkan stasiun P5 berkisar antara 1,0986-1,19355 berarti stabilitas komunitas biota sedang atau kualitas air tercemar sedang.

Fitoplankton memiliki klorofil yang berperan dalam fotosintesis untuk menghasilkan bahan organik dan oksigen dalam air yang digunakan sebagai dasar mata rantai pada siklus makanan di laut. Namun fitoplankton tertentu mempunyai peran menurunkan kualitas perairan laut apabila jumlahnya berlebih (blooming) (Anderson, et al., 2008). Tingginya populasi fitoplankton beracun di dalam suatu perairan dapat menyebabkan berbagai akibat negatif bagi ekosistem perairan, seperti berkurangnya oksigen di dalam air yang dapat menyebabkan 
kematian berbagai makhluk air lainnya (Damar, 2006).

Ledakan populasi fitoplankton yang diikuti dengan keberadaan jenis fitoplankton beracun akan menimbulkan Ledakan Populasi Alga Berbahaya (Harmful Algae Blooms $H A B s)$. Faktor yang dapat memicu ledakan populasi fitoplankton berbahaya antara lain karena adanya eutrofikasi adanya upwelling yang mengangkat massa air kaya unsur-unsur hara; adanya hujan lebat dan masuknya air ke laut dalam jumlah yang besar (Wiadnyana, 1996). Beberapa penyakit akut yang disebabkan oleh racun dari kelompok fitoplankton berbahaya adalah Paralytic Shellfish Poisoning (PSP), Amnesic Shellfish Poisoning (ASP), dan Diarrhetic Shellfish Poisoning (DSP). Racun-racun tersebut sangat berbahaya karena di antaranya menyerang sistem saraf manusia, pernapasan, dan pencernaan. Semua penyakit di atas berkaitan dengan konsumsi kerang oleh manusia (Praseno dan Sugestiningsih, 2000).

Spesies HABs yang paling banyak ditemukan berasal dari kelas Dinophyceae. Hal ini dikarenakan Dinophyceae dapat membentuk sista (cyst) sebagai tahap istirahat, sista ini mengendap di dasar laut dan istirahat sampai kondisi lingkungan mendukung kembali untuk tumbuh (Nontji, 2006). Anggota dari kelompok ini diketahui paling banyak mempunyai jenis-jenis toksik (Praseno, dan Sugestiningsih, 2000).

Nitzschia sp. merupakan spesies penyebab Amnesic Shellfish Poisoning (ASP) yang mengeluarkan toksin asam domoic. Toksin yang diproduksi dapat memasuki rantai makanan hingga ke tubuh manusia melalui perantara kerang. Kerang merupakan organisme bentik suspension feeder yang menyaring plankton yang melimpah di kolom air (Nybakken, 1992). Chaetoceros sp., spesies HABs tertinggi kedua setelah Nitzschia sp., merupakan spesies fitoplankton yang tidak toksik terhadap manusia tetapi secara fisik dapat mengganggu sistem pernafasan ikan dan avertebrata terutama apabila kepadatan individunya relatif tinggi. Diatom jenis ini mempunyai morfologi khas yaitu duri. Duri-duri tersebut dapat merangsang pembentukan lendir pada insang biota laut, sehingga biota tersebut sukar bernafas. Duri-duri ini bahkan dapat menyebabkan pendarahan di insang (Praseno dan Sugestiningsih, 2000). Chaetoceros merupakan jenis fitoplankton yang diketahui mampu bertahan di perairan tercemar (Fachrul, Haeruman, dan Sitepu, 2005).

\section{KESIMPULAN}

Berdasarkan hasil penelitian dari pengambilan sampel fitoplankton di perairan Teluk Lalong maka dapat disimpulkan jenis fitoplankton yang didapatkan di perairan Teluk Lalong antara lain : Chaetoceros sp, Skeletonema sp, Nitzschia sp, Pontosphaera sp, Dinobryon sp, Ceratium sp, dan Coscinodiscus sp. Kelimpahan individu berkisar antara 1.274-29.300 ind/L, indeks keanekaragaman berkisar antara 0-1,19355, indeks keseragaman berkisar antara 0-0,999997, indeks dominansi berkisar antara 0,33333-1. Berdasarkan kelimpahan fitoplankton, perairan Teluk Lalong dikategorikan oligotrofik, mesotrofik dan eurotrofik. Sedangkan berdasarkan indeks keanekaragaman, perairan Teluk Lalong dikategorikan tercemar sedang dan tercemar berat.

\section{SARAN}

Pemerintah Daerah Kabupaten Banggai agar melakukan monitoring secara kontinyu terhadap kelayakan lingkungan di perairan Teluk Lalong dan merumuskan langkah-langkah kebijakan untuk menekan tingkat pencemaran di sekitar perairanTeluk Lalong Luwuk. 
DAFTAR PUSTAKA

Anderson, D,M., et al. 2008. Harmful Algall Blooms And Eutrophication: Examining Linkages From Selected Coastal Region Of The United Stated, Harmful Algae. 8. 39-53.

APHA (American Public Healt Association). 2003. Standard Methods for the Examination of Water and Wastewater. American Public Health Association. Washington, DC. 874 p.

Basmi. 2000. Planktonologi : Plankton Sebagai Indikator Kualitas Perairan. Fakultas Perikanan dan Ilmu Kelautan. Institut Pertanian Bogor. 60 hlm.

Clark, W., and P.L. Hosking. 1986. Statical Methods for Geographers. New York: John Wiley and Sos, Inc.

Damar, A. 2006. Musim Hujan Dan Eutrofikasi Perairan Pesisir. Majalah Tempo. 30 Nopember 2006.

Effendi, H. 2003. Telaah Kualitas Air. Kanisius. Yogyakarta.

Fachrul, M F, Haeruman H, Sitepu L C, 2005. Komunitas Fitoplankton Sebagai Bioindikator Kualitas Perairan Teluk Jakarta. Seminar Nasional MIPA. Universitas Indonesia. Jakarta.

Newel, G.E. and R.C. Newel. 1977. Marine Plankton. London: Hutchintson.

Nontji, A.. 2006. Tiada Kehidupan Di Muka Bumi Tanpa Plankton. Pusat Penelitian Oseanografi - LIPI. Jakarta.

Nybakken, J.W. 1992. Biologi Laut Suatu Pendekatan Ekologis. PT. Gramedia. Jakarta. 459 hal.

Odum, P.E. 1971. Fundamentals of Ecology. Saunders College Publishing. Rinehart and Winston, Inc. Translation Copyright 1993 by Gadjah Mada University Press.

Pirzan, A.M., Utojo, M. Atmomarso, M. Tjaronge, A.M. Tangko, dan Hasnawi. 2005. Potensi Lahan Budi Daya Tambak Dan Laut di Kabupaten Minahasa, Sulawesi Utara. Jurnal Penelitian Perikanan Indonesia 11 (5): 43-50.

Praseno, D,P. dan Sugestiningsih. 2000. Red Tide Di Perairan Indonesia. Pusat
Penelitian dan Pengembangan

Oseanologi - LIPI. Jakarta.

Wiadnyana, N,N. 1996. Mikroalga Berbahaya

Di Indonesia. Oseanology dan Limnology di Indonesia. 29. 15 - 28.

Widodo, J. 1997. Biodiversitas sumber daya perikanan laut peranannya dalam pengelolaan terpadu wilayah pantai. Dalam: Mallawa, A., R. Syam, N. Naamin, S. Nurhakim, E.S. Kartamihardja, A. Poernomo, dan Rachmansyah (ed.). Prosiding Simposium Perikanan Indonesia II, Ujung Pandang, 2-3 Desember 1997. Penyelenggara : Pusat Penelitian dan Pengembangan Perikanan bekerjasama dengan Japan International Coorporation Agency, Universitas Hasanuddin, Dinas Perikanan Dati I Sulsel, Ikatan Sarjana Perikanan Indonesia, dan Himpunan Mahasiswa Perikanan Indonesia.

Yamaji. J. 1976. Illustration of Marine Plankton. Osaka: Hoikush Publishing Co. Ltd. 